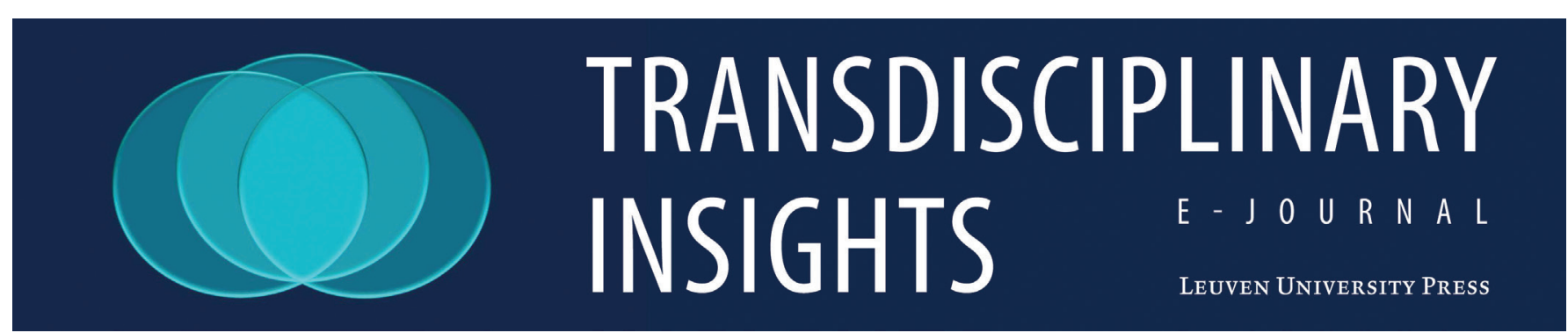

\title{
HIV-related Peer Support in Dar es Salaam: A Pilot Questionnaire Inquiry
}

\author{
Anneleen Kiekens, ${ }^{1,2 \$}$ Joram Dehens, ${ }^{1,3}$ Maud \\ de Hemptinne, ${ }^{1,4}$ Michaël Galouchka, ${ }^{1,5}$ Cedric \\ Vanhoorebeeck, ${ }^{1,5}$ Reinier Petrus van Otzel, ${ }^{1,5}$ \\ Magorzata Wyszkowska, ${ }^{1,6}$ Saar Baert, ${ }^{7}$ Edwin \\ J Bernard, ${ }^{8}$ Jorge Ricardo Nova Blanco, ${ }^{1,2}$ Tim \\ Dierckx, ${ }^{2}$ Fausta Mosha, ${ }^{9}$ Raphael Zozimus \\ Sangeda, ${ }^{1}$ Kristof Theys, ${ }^{2}$ Astrid Van den \\ Eede, ${ }^{1}$ Michael R Jordan, ${ }^{11,12}$ Anne-Mieke \\ Vandamme ${ }^{2,13}$ \\ ${ }^{1} \mathrm{KU}$ Leuven, Transdisciplinary Insights Honours \\ Programme, Institute for the Future, Leuven, Belgium; \\ ${ }^{2} \mathrm{KU}$ Leuven, Department of Microbiology and \\ Immunology, Rega Institute for Medical Research, \\ Clinical and Epidemiological Virology, Leuven, Belgium; \\ ${ }^{3} \mathrm{KU}$ Leuven, Master's student Mechanical \\ Engineering, Leuven, Belgium; \\ ${ }^{4} \mathrm{KU}$ Leuven, Master's student Biomedical Sciences, \\ Leuven, Belgium; \\ ${ }^{5} \mathrm{KU}$ Leuven, Master's student Medicine, Leuven, \\ Belgium; \\ ${ }^{6} \mathrm{KU}$ Leuven, Master's student Arts in Cultural Studies, \\ Leuven, Belgium; \\ ${ }^{7}$ Médecins Sans Frontières, Operational Centre \\ Brussels, Belgium; \\ ${ }^{8}$ HIV Justice Network, Brighton, UK; \\ ${ }^{9}$ National Health Laboratory Quality Assurance and \\ Training Center, Dar es Salaam, Tanzania; \\ ${ }^{10}$ Department of Pharmaceutical Microbiology, \\ Muhimbili University of Health and Allied Sciences, \\ Dar es Salaam, Tanzania;
}

\author{
${ }^{11}$ Tufts University School of Medicine, Boston, USA; \\ ${ }^{12}$ Tufts Medical Center, Boston, USA; \\ ${ }^{13}$ Center for Global Health and Tropical Medicine, \\ Unidade de Microbiologia, Instituto de Higiene e \\ Medicina Tropical, Universidade Nova de Lisboa, \\ Lisbon, Portugal. \\ \$Corresponding author: anneleen.kiekens@ \\ kuleuven.be
}

\section{Abstract}

HIV drug resistance (HIVDR) in Tanzania is a complex problem with many interconnected causes. Some important factors contributing to the selection of drug resistant viruses in people infected with HIV are stigma, poverty, poor health, illiteracy, and insufficient adherence to antiretroviral therapy. Several studies have suggested the implementation of peer support groups as a way to shift the workload associated with adherence support, antiretroviral therapy (ART) distribution, and HIV education away from the doctors to the people living with HIV (PLHIV) themselves. We conducted interviews with local PLHIV to investigate the desirability and feasibility of a peer support group in the Pasada and Kisarawe hospitals in Dar es Salaam, Tanzania. A standardized questionnaire was completed by 27 PLHIV in July and August 2017 at the time of a follow-up visit. In this cohort, major causes for missing a dose of ART are lack of support from family and friends and forgetfulness. Reasons for wanting to join 
a peer support group include psychological support, fighting stigma, and increasing education about their disease. Interestingly, several respondents linked HIV peer support to business support groups such as village community banks (VICOBA). These are informal microfinance groups meant to offer economic stability to individuals. As this link was made by PLHIV themselves, we suggest that it may be worthwhile to explore mixed financial and HIV peer support groups in which HIV education is provided for both HIV positive and negative members. Such groups may reduce the risk of infection and stigma and provide combined psychological, financial, and logistic support to PLHIV.

\section{Key words}

HIV, HIVDR, transdisciplinarity, peer support, microfinance groups

\section{Introduction}

Current antiretroviral therapy (ART) is capable of lifelong suppression of the human immunodeficiency virus (HIV), resulting in a patient life expectancy approaching that of the general population (Trickey, 2017). However, pre-treatment drug resistance to nonnucleoside reverse transcriptase inhibitors (NNRTI), an important class of HIV drugs, is rising. Prevalence estimates in Sub-Saharan Africa report that up to 23.6 percent in South Africa and 15.4 percent of infected individuals have pre-treatment NNRTI resistance in Uganda (WHO, 2019). Also the prevalence of acquired drug resistance among individuals on first-line ART who have an unsuppressed viral load after 12 months is worrying (up to 97 percent in Uganda) (WHO 2019).

Many causes of both pre-treatment and acquired HIV drug resistance (HIVDR) have been identified. The most important one is insufficient adherence to therapy resulting from several factors, such as limited drug availability, ineffective patient-doctor relationships, fear of stigmatization, side effects of the drugs, and treatment interruption due to disengagement from care (Altice, Mostashari, \& Friedland, 2001; Van Tam, Pharris, Thorson, Alfven, \& Larsson, 2011). Adressing these problems is not straightfordward, as each individual cause can be the result of a whole range of influencing factors that differ on an individual basis, by culture, healthcare center, etc. Moreover, the conditions that give rise to these problems can shift in time so that other or new aspects become salient. As such, any solution to the problem is only ever a partial solution. HIVDR is therefore a "wicked" problem which requires a transdisciplinary and people-centered approach to solving it.

One major contributing factor relevant to many aspects of the HIVDR problem is the shortage of healthcare staff. In 2014 the World Health Organization (WHO) estimated the number of physicians in Tanzania to be 0.399 per 10,000 inhabitants, ${ }^{1}$ and in rural areas this number is even lower. To shift the workload from physicians to the people living with HIV (PLHIV) themselves, different forms of peer support have been introduced across settings (Decroo, 2017). In such peer support groups PLHIV support each other both psychologically and logistically, for example by taking turns in picking up ART at the hospital, thereby reducing the number of hospital visits per PLHIV.

This article builds upon the work of a transdisciplinary team at $\mathrm{KU}$ Leuven which investigated the complexity of HIVDR in Tanzania in 2017 (Dehens et al., 2017A; Dehens et al., 2017B). The team investigated the feasibility and acceptability of peer support groups for PLHIV enrolled in the ART programme of the Pasada and Kisarawe hospitals in Dar es Salaam, Tanzania, using a transdisciplinary approach combined with relevant stakeholder interviews. We designed a questionnaire in order to solicit the opinion of HIV positive individuals about peer support groups. In what follows we describe the results of those questionnaires filled in by HIV positive adults enrolled in the Pasada and Kisarawe hospitals.

\section{Methods}

The questionnaires were designed by a transdisciplinary team at KU Leuven with the help of HIV experts at NGOs, universities and research institutions, and governmental institutions. The transdisciplinary process used for developing the questionnaire is described by Dehens etal., (2017B). The questionnaires were designed in English and subsequently translated into Kiswahili (attachment 1 and 2). The study was conducted in Dar es Salaam, Tanzania, from July to August 2017. The study population consisted of adult PLHIV (both male and female) who were registered at the ART program in the Pasada and Kisarawe hospitals. PLHIV visiting the Pasada and Kisarawe hospitals for their check-ups were invited by their healthcare 
workers to provide their informed consent and fill in the questionnaire.

Ethical permission to conduct the study was obtained from the National Institute for Medical Research in Tanzania. Any patient identifiers were removed from the data collection before the data were shared with the researchers in Belgium.

The questionaires were analyzed using RStudio ( $R$ version 3.4.2) and written answers were taken into account for the interpretation of the data.

\section{Results and Discussion}

\section{Demographic data}

Data on 27 participants (13 male, 11 female, 3 participants did not indicate their gender) were analyzed (Figure 1A). Participants were of the following age groups: $18-20$ years (3/27), 20-40 years (11/27), and 40-65 years (10/27) (Figure 1B). Of the
27 respondents, 22 belonged to the lowest income category with an income of less than 100,000 Tanzanian shillings (Tsh) monthly, which equates to 40 Euros or 45 USD at the time of the study, 2017. Two participants earned between 100,000 and 500,000 Tsh per month (40-200 Euros or 45-230 USD) and one earned between 500,000 and 1,500,000 Tsh monthly (200-600 Euros or 230-680 USD) (Figure 1C). None of the participants reported earning more than 1,500,000 Tsh (600 Euros or 680 USD) per month. Two participants spent less than one hour in picking up their medication, 7 spent 2-4 hours, 11 participants spent 4-6 hours and five of the 27 participants took more than 6 hours traveling to pick up their ART refills (Figure 1D). When asked to indicate how happy they were with the current amount of time needed to pick up their medication on a scale of one to eight $(1=$ not happy at all, $8=$ very happy), the participants answered with on average 5.44 (standard deviation: 1.73).

\section{Demographic data of the 27 participants}

A

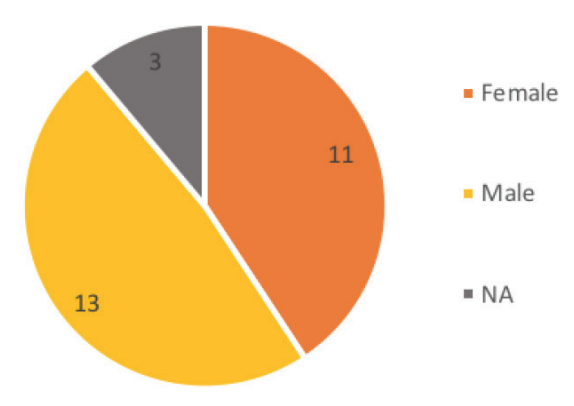

C Income Range $x 1000$ (Tsh)

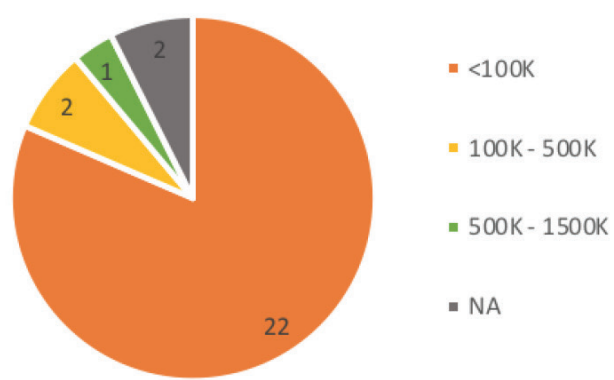

B

Age Group (years)

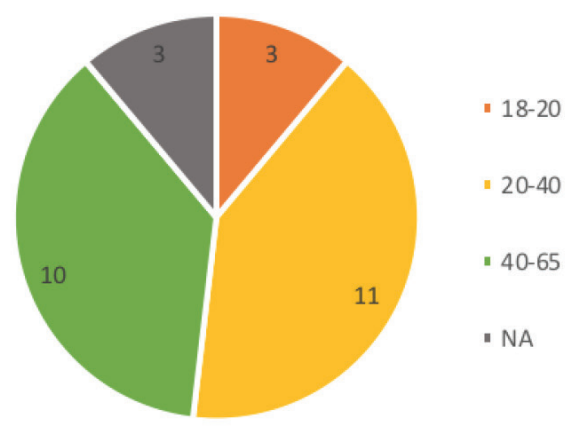

D Time needed to pick up ART (h)

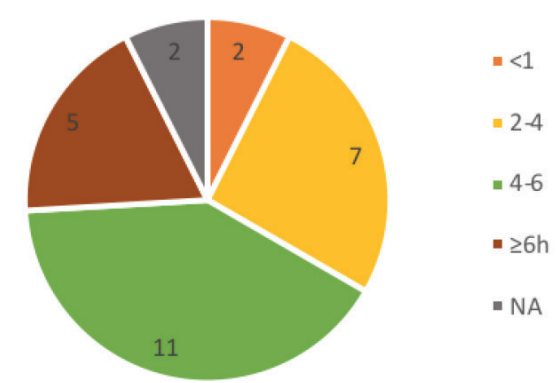

Figure 1. Demographic data of the 27 participants: A) Gender B) Age C) Income range D) Approximate time needed to pick up ART. Abbreviations: NA = not answered, Tsh = Tanzanian Shilling, ART = Antiretroviral therapy, $h=$ hour 


\section{Adherence}

Respondents indicated a median of 2 reasons (median average deviation, $M A D=1$ ) when asked what the main reasons were for missing a dose of ART. Almost half of the respondents (13/27) indicated never having missed taking their ART (Figure 2). However, although denying missing doses, 10 of these 13 respondents did indicate reasons for missing doses of ART. This apparently contradictory finding suggests that the respondents may not have felt comfortable confessing adherence issues to the healthcare worker who interviewed them. The two most frequently observed reasons for missing a dose of ART were simply forgetting to take the dose $(8 / 27)$ and lacking support from family or friends (7/27). Other answers written in the free field by the participants themselves included: "I don't take the medication when I don't have food", "There are no jobs" and "When I have an unplanned trip I don't carry medicine". Only two of the respondents answered that they were not sure how and when to take the ART.

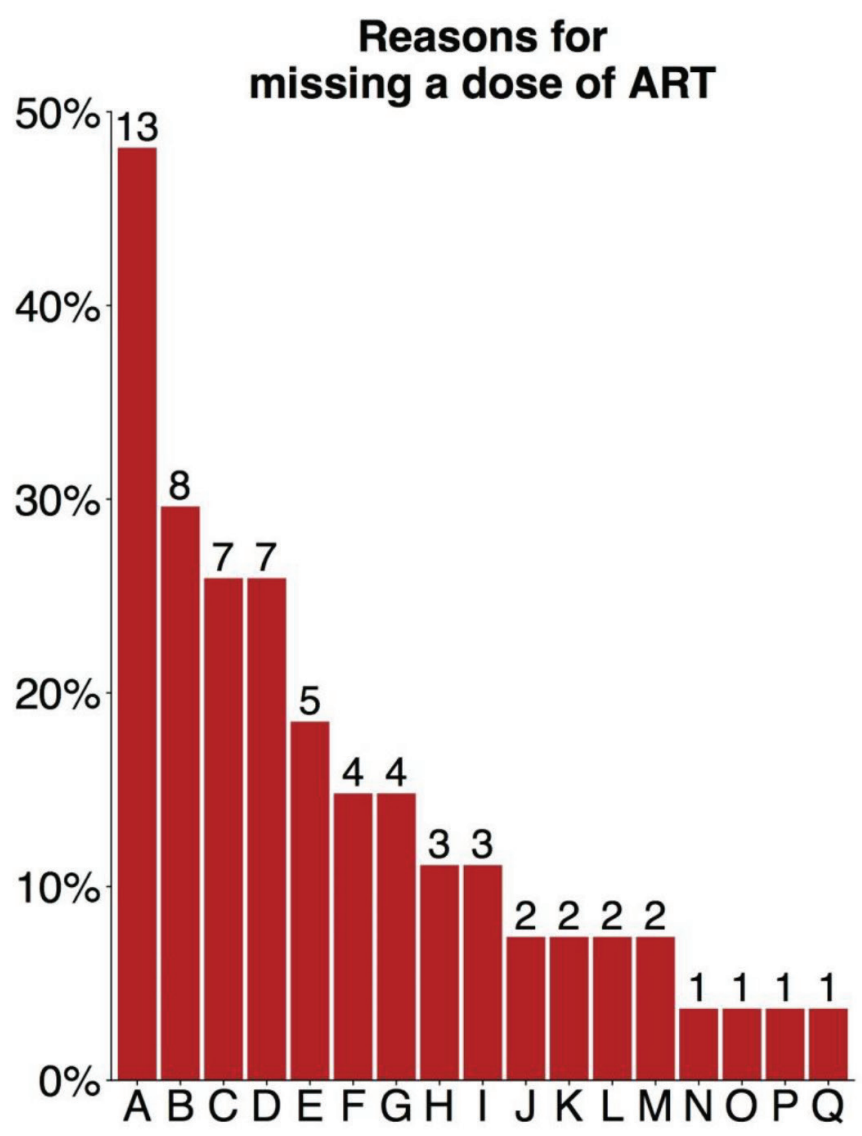

Figure 2. Reasons indicated for missing a dose of ART.
In contrast, when answering the question "which of the following help would make you take your pills properly" more than half of the participants $(15 / 27)$ indicated that "information on when and how to take the pills" would be of help (Figure 3), suggesting the majority of participants are not entirely confident about how to take the pills. Other common answers were "automatic reminders via messages/apps" (12/27), "less stigma" (18/27) and "HIV education in the community" (17/27). Also support from doctors, nurses, and family and friends was often indicated (11/27, 9/27 and $7 / 27$, respectively). Participants indicated a median of 3 options $(M A D=2)$ of preferred adherence support.

\section{Peer support group}

The vast majority of the respondents (25/27) indicated that they thought organizing peer support groups, led by an expert patient, would be helpful (Figure 4A). To this question $2 / 27$ participants provided no response. Out of the 27 participants, 22 indicated interest in
A. I never missed taking my pills
B. Simply forgot
C. I lack support from family/friends
D. Other
E. Too much time lost in picking up medication
F. I don't want to take medication
G. The medication tastes bad
H. I lack support from my community
I. I am not sure the medication is working
J. I don't have enough privacy at the clinic
K. Not sure how and when to take the pills
L. Difficulty swallowing
M. No time
N. Pharmacy out of stock
O. I lack support from hospital staff
P. I don't have enough privacy to take pills
$\mathrm{Q}$. The drugs make me feel sick

\section{Other answers}

"When I have an unplanned trip I don't carry medicine."

"After I received a divorce."

"I lacked means of getting medicines when medicine was finished."

"To go fishing without medicine."

"He has never forgotten to take his medication." "I don't take medicine when I don't have food."

"There are no jobs." 


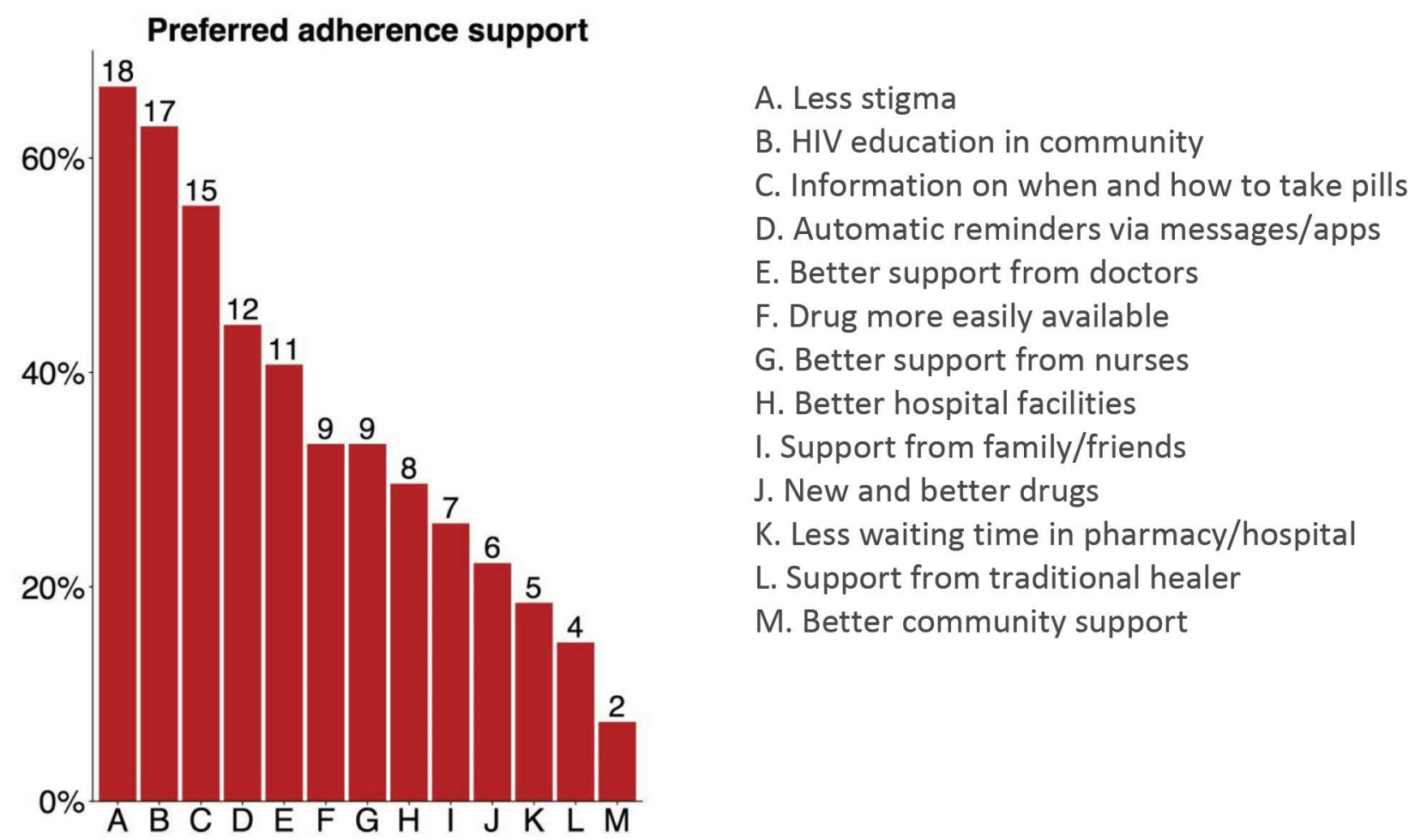

Figure 3. Respondents indicated which measures they think would help them to adhere.

attending peer support sessions led by expert patients (Figure 4B). However, when asked whether they would join a peer support group where medication could be received, so that they did not have to pick up the medication at the hospital, 14 responded yes and 10 responded no (Figure 4C). This suggests that the reasons for being interested in joining a peer support group are diverse, and that for only some of the participants ART distribution would be a driving factor for joining a peer support group. Similarly, when asked to specify what help was preferred from an expert patient, only 3 participants indicated the facilitation of pill pick up. Together these results suggest that the main reasons for joining a peer support group would be for psychological support rather than practical reasons. Indeed, the main preferred help from peer experts appeared to be "motivation to take the medication as prescribed", "emotional support" and "tackling stigma" (Figure 5). Participants indicated a median of 3 options $(M A D=1)$ of preferred help from peer experts.

The limited number of medical staff is a major challenge in Tanzania (Goodell et al. 2016). As a possible solution to this problem, peer support groups have been proposed where PLHIV educate each other and take turns picking up medication for each other, reducing the workload of the doctors. However, the results of this study indicate that PLHIV do not necessarily want to visit the hospital less often (figure 4C). This could be explained by wanting to feel in control of one's own health situation or the intangible value seen in visiting a healthcare provider, and may differ between different settings or social groups. Moreover, studies have shown that peer support groups do have the potential to increase adherence rates (Decroo, 2017). It might be that the participants need some time to adjust to the idea of visiting the healthcare center less often and to gain trust in the functioning of the peer support group.

In line with that are the answers to the question "Would you feel more or less likely to take your drugs if you didn't visit the hospital as often?". Only 7 of the respondents indicated that they would expect to adhere better to their treatment; the other respondents predicted they would take their ART less often (5/27), the same (7/27), or were unsure (3/27) (Figure 4D).

A short description defining an expert patient was provided in the questionnaire: "To become an 'expert patient' a person with HIV will receive training by healthcare professionals in a short training program. Then they will voluntarily use their knowledge to support and educate fellow patients. Tasks could include being group leader, gathering information, 
distributing medication to other patients, becoming an educator etc.)." 18 respondents indicated interest in becoming an 'expert patient' (Figure 4E). Of the two respondents who answered "maybe", one admitted to being insecure about becoming an expert patient because he had no formal education. The majority $(17 / 27)$ of the respondents preferred to have peer support groups meet monthly rather than weekly (7/27).

\section{Respondents' view on peer support groups}

\section{A Do you think peer support groups lead by 'expert patients'} are a good idea?

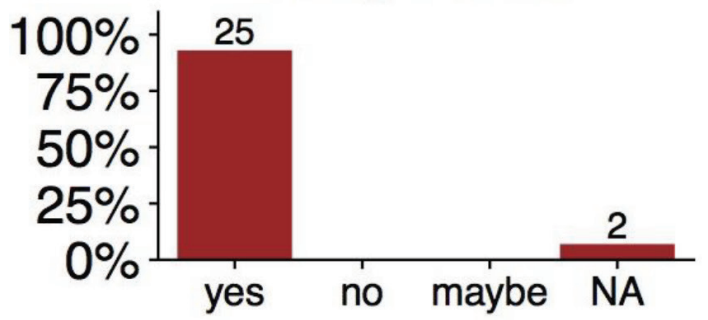

C

Are you interested in joining a peer support group in order to facilitated pill pickup?

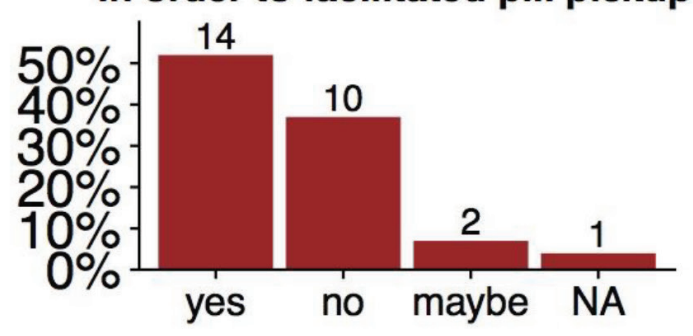

E

Would you be interested in becoming an 'expert patient'?

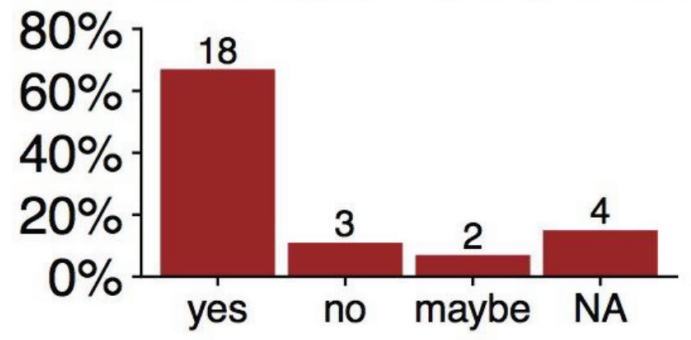

B

Would you like to attend regular peer support sessions led by an 'expert patient'?

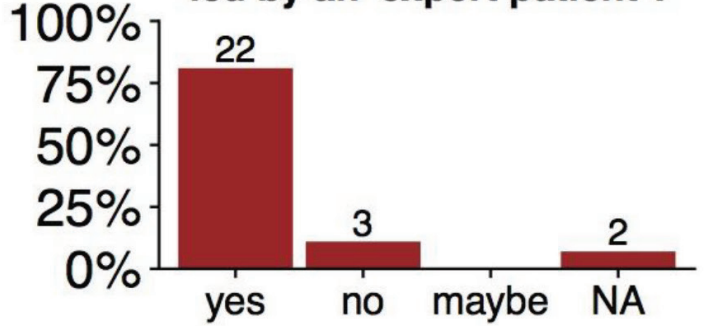

D

\section{Predicted adherence in case of reduced hospital visits}

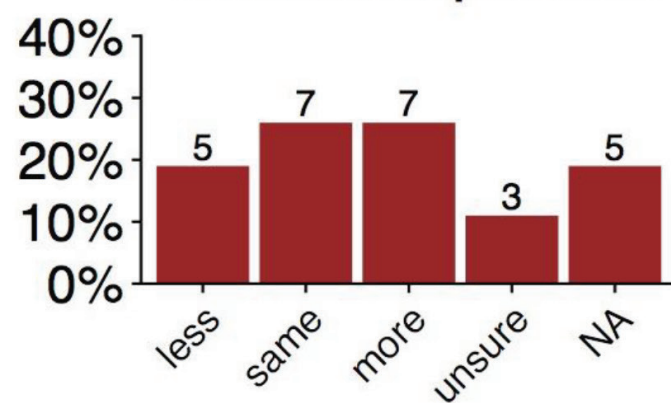

$\mathbf{F}$

How often would you be willing to attend peer support sessions?

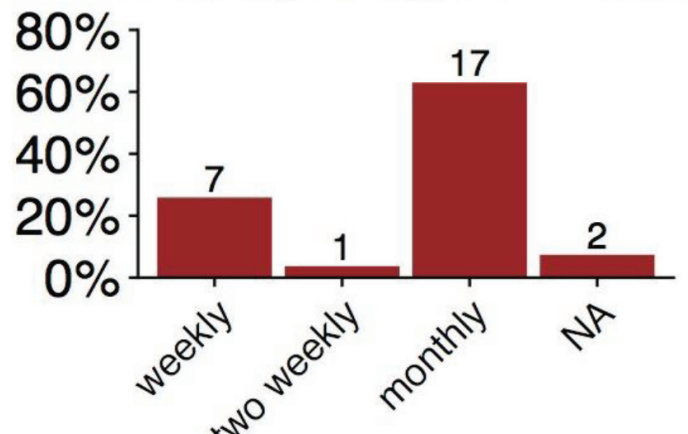

Figure 4. Respondents'view on peer support: A) general view on peer support. B) interest in joining a peer support group. C) interest in joining a peer support group with focus on facilitating pill pick up. D) self-predicted adherence when hospital visits are reduced. E) interest in becoming an 'expert patient'. F) frequency of peer support sessions. 


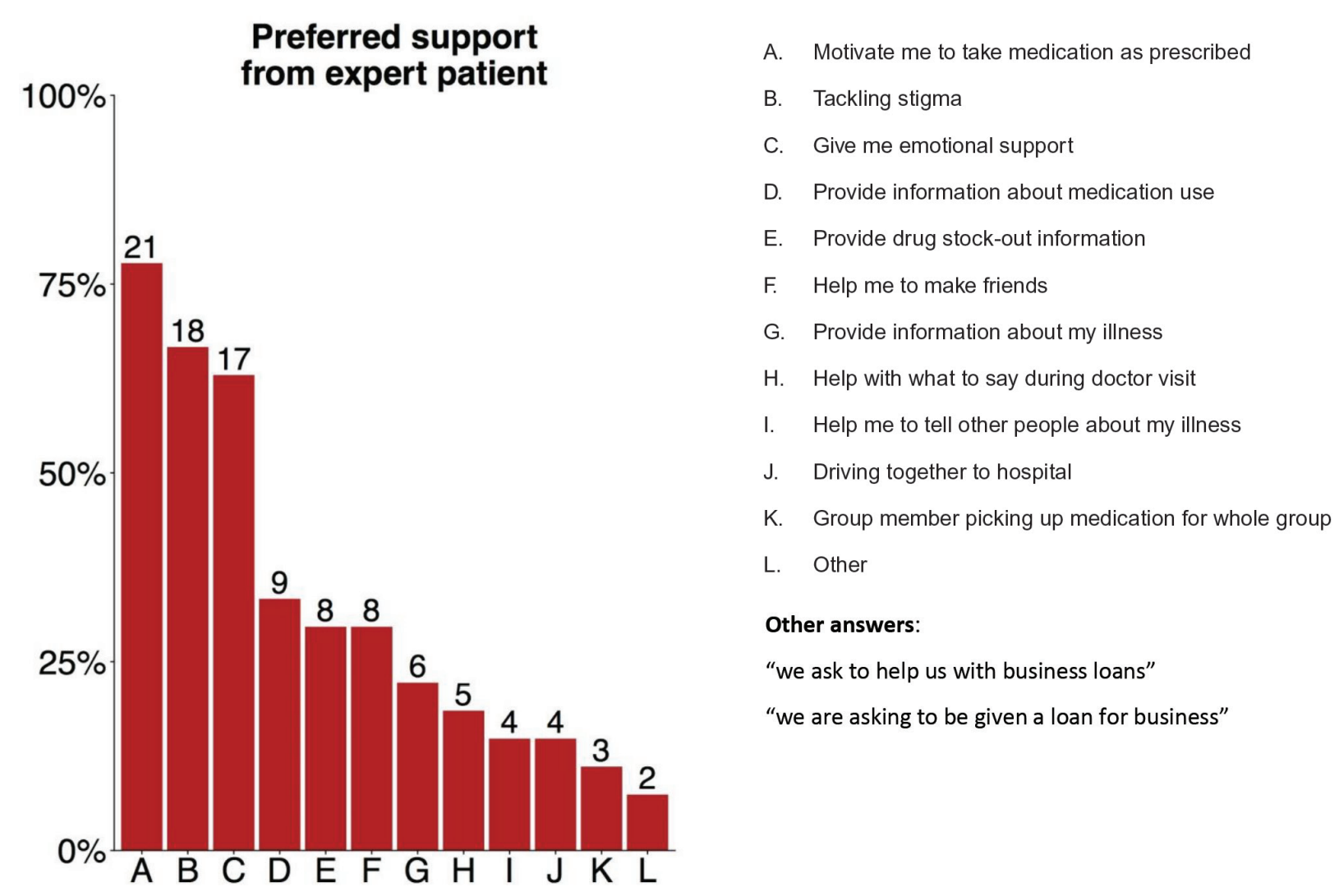

Figure 5. Respondents indicated the ways in which they feel an expert patient can support them.

\section{VICOBA}

Interestingly, although the topic "business" was never mentioned in the questionnaire, 7 (6 female and 1 male) of the 27 respondents referred to their business or asked for a business loan in one of the open-ended questions (attachement 1 and 2). Answers included "we are asking to be given a loan for business", "to help each other economically" and "entrepreneurship". A description of our vision of peer support groups was in the questionnaire, so it is not clear to us whether the respondents interpreted the concept 'peer support group for HIV' in a different way, or whether they simply wanted to express their greatest need. Microfinancing groups in the form of village community banks (VICOBA) are common practice in Tanzania. These are an informal social protection mechanism meant to provide economic stability to individuals.

Regardless of the different interpretations of the 'peer support' concept, it is apparent that some people living with HIV link the concept of peer support groups to their economic status. This suggests that it may be valuable to explore in further research whether peer support groups could be organized with a dual purpose: 1) psychological, logistic, and educational HIV treatment support and 2) financial support related to business purposes.

A recent study in Tanzania, Mtenga et al. (2018), reported that being a member of a VICOBA is statistically significantly associated with an increased number of extramarital affairs, which was significantly linked with HIV infections for women only (Mtenga, Pfeiffer, Tanner, Geubbels, \& Merten, 2018). Due to their poor financial situation, women often form part of more than one VICOBA and are unable to keep up with their membership payments. Men often refuse to support their wives in repaying their VICOBA loans, which, according to the findings of Mtenga et al., may be related to the fear of losing control over their wives should they become financially independent. As a result, women may engage in extramarital affairs with men who help them to repay their debts and provide them with food or other material support. The financial hardship of women can explain why in our study 6 out of 7 respondents who mentioned business and loans were women. This contrasts sharply with the expectation of social protection mechanisms such as VICOBA, the intent of which includes lowering vulnerability to HIV infection (Temin, 2010). 
Given our findings and those of Mtenga et al. (2018), we propose that VICOBA or other microfinance systems in Tanzania could be an interesting platform for raising HIV awareness and education, but also to provide combined economic and HIV peer support. A study by Lushakuzi et al. (2017) in Dar es Salaam indicated that in order for a VICOBA to bring benefit to its participants, training to improve business skills and frequent supervision should be provided, as the provision of money alone is insufficient for adequate performance of the VICOBA members' businesses (Lushakuzi, Killagane, \& Lwayu, 2017). This indicates that members of well-functioning VICOBA are accustomed to training sessions and to being supervised, which would make the step to inclusion of HIV peer support smaller. VICOBA group membership includes HIV positive and HIV negative individuals and it is primarily focused on a topic other than HIV. Building HIV education and awareness into this existing peer support structure may potentially reduce the second component of stigma as described by Link et al.: "associating human differences with negative attributes" (Link \& Phelan, 2001). For example, an HIV positive guest speaker presenting on a business topic could help to reduce the negative associations that the group members may have with HIV.

\section{Conclusion}

In this study we explored the opinions of PLHIV about the potential for introducing peer support groups led by peer experts in Dar es Salaam, Tanzania. Such groups could not only reduce the workload of the healthcare system by distributing ART in the community, but could also help to improve adherence, tackle stigma, and provide needed psychosocial support to people living with HIV. We learned that PLHIV expect such peer support will help them cope with psychological issues like stigma; they were less interested in practical issues like ART distribution in the community.

Without the intention of investigating the topic of business, the authors noticed that some PLHIV in this study link peer support groups for HIV with support groups for business purposes (such as VICOBA). Further research on this topic is needed to investigate whether and how HIV peer support can be combined with VICOBA or other microfinance groups while reducing the association between HIV and extramarital affairs linked to the VICOBA. The link between peer support and business support coming solely from the respondents indicates the importance and potential of further research on this topic.

\section{Acknowledgements}

The authors would like to thank Abdus Shuman Sajud (KU Leuven) and Marc Thompson (Project 100, Positively UK) for their valuable insights when developing the questionnaire. We would also like to thank Carolyn Riwa of the National Health Laboratory Quality Assurance and Training Center, Dar es Salaam, Tanzania, for coordinating the questionnaires, and the health workers and patients of the Pasada and Kisarawe hospitals for their time and effort in conducting the questionnaires.

\section{Supplementary Material}

1. English questionnaire

2. Kiswahili questionnaire

3. Raw data

\section{Note}

${ }^{1}$ http://www.who.int/gho/health_workforce/physicians density/en/ (accessed on August 12, 2019).

\section{References}

Altice, F. L., Mostashari, F., \& Friedland, G. H. (2001). Trust and the acceptance of and adherence to antiretroviral therapy. Journal of Acquired Immune Deficiency Syndromes. https://doi.org/10.1097/0012 6334-200109010-00008

Decroo, T. (2017). Community-based ART in sub-Saharan Africa: lessons learnt from Community ART Groups in Tete province, Mozambique.

Goodell, A. J., Kahn, J. G., Ndeki, S. S., Kaale, E., Kaaya, E. E., Macfarlane, S. B. J. (2016). Modeling solutions to Tanzania's physician workforce challenge. Glob Health Action 2016, 9: 31597 - http://dx.doi.org/10. 3402/gha.v9.31597

Joram Dehens, Maud de Hemptinne, Michaël Galouchka, Abdus Sajud, Reinier Petrus van Otzel Cedric Vanhoorebeeck, Małgorzata Wyszkowska, Anneleen Kiekens, Jorge Ricardo Nova Blanco, A.-M. V. (2017). Transdisciplinary experience in a pilot year of the new Honours Programme at the KU Leuven - University of 
Leuven: building a team, developing and improving a transdisciplinary project through addressing a challenge on HIV drug resistance in Africa, 1(1), 33-39. https://doi.org/10.13748/j.cnki.issn1007-7693. 2014.04.012

Joram Dehens, Maud de Hemptinne, Michaël Galouchka, Abdus Sajud, Reinier Petrus van Otzel, Cedric Vanhoorebeeck, Małgorzata Wyszkowska, Fausta Mosha, Raphael Sangeda, Tulio de Oliviera, Edwin Bernard, Marc Thompson, Anneleen Kiekens, Saar Baert, Andreas D, A.-M. V. (2017). Exploring the value and acceptability of peer support in the process of improving adherence to HIV antiretroviral drugs in Tanzania, Dar-es-Salaam. Trandisciplinary Insights, 1(1).

Link, B. G., \& Phelan, J. C. (2001). Conceptualizing Stigma Author ( s ): Bruce G . Link and Jo C . Phelan Published by: Annual Reviews Stable URL: http://www.jstor.org/ stable/2678626 Your use of the JSTOR archive indicates your acceptance of the Terms \& Conditions of Use, available at CO, 27(May), 363-385.

Lushakuzi, S. S., Killagane, K., \& Lwayu, G. E. (2017). Village Community Banks (VICOBA) and Members' Business Sustainability: Case study of Kunduchi Ward at Kinondoni District in Dar es Salaam. International Journal of Business Marketing and
Management Www.ljbmm.Com International Journal of Business Marketing and Management, 2(3), 60-70.

Mtenga, S. M., Pfeiffer, C., Tanner, M., Geubbels, E., \& Merten, S. (2018). Linking gender, extramarital affairs, and HIV: a mixed methods study on contextual determinants of extramarital affairs in rural Tanzania. AIDS Research and Therapy, 1-17. https://doi. org/10.1186/s12981-018-0199-6

Temin, M. (2010) 'HIV-sensitive Social Protection: What Does the Evidence Say'. Geneva, New York, Brighton: UNAIDS, UNICEF, IDS.

Trickey, A. (2017). Survival of HIV-positive patients starting antiretroviral therapy between 1996 and 2013: a collaborative analysis of cohort studies. The Lancet HIV, 4, e349-e356. https://doi.org/10.1016/ S2352-3018(17)30066-8

Van Tam, V., Pharris, A., Thorson, A., Alfven, T., \& Larsson, M. (2011). "It is not that I forget, it's just that I don't want other people to know": barriers to and strategies for adherence to antiretroviral therapy among HIV patients in Northern Vietnam. AIDS Care, 23(2), 139-145. https://doi.org/10.1080/09540121.20 10.507741

WHO. (2019). Hiv drug resistance report 2019. Retrieved from https://www.who.int/hiv/pub/drugresistance/ hivdr-report-2019/en/. 
Supplement 1: English Questionnaire

\section{Peer support questionnaire (English)}

Interviewer:

Patient's number:
Date:

Study number:

\section{Instructions:}

You are part of a pilot study to explore if peer support is acceptable to you and what your concerns could be. Your answers will help health workers to improve the care for people receiving ARVs. Please answer the following questions as truthfully as you can - tell us what you personally think, and not what you think you want us to hear. Your responses will be anonymized and not be traced back to you.

\section{BASIC QUESTIONS}

a. What is your age?
[ ] under 20;
[ ] 20-40;
[ ] 40-65;
[ ] $>65$

b. What is your sex?
[ ] Male;
[ ] Female;
[ ] Other

c. Which is your income range?
[ ] Less than 100,000 Tsh
[ ] 500,000 Tsh - 1,500,000 Tsh
[ ] 100,000 Tsh to 500,000 Tsh
[ ] More than 1,500,000 Tsh

d. When did you first have a positive HIV test result? (year)

\section{PATIENT SUPPORT GROUP}

a. Most patients experience some difficulties taking their drugs, the reason why can vary. If you missed taking your pills, what was the main reason? You can tick more than one box.
[ ] I never missed taking my pills
[ ] The drugs make me feel sick
[ ] pharmacy stock-out
[ ] I am not sure the medication is working
[ ] too much time lost to pick up medication
[ ] not sure how and when to take the pills
[ ] I lack support from family/friends
[ ] the medication tastes bad
[ ] I lack support from hospital staff
[ ] difficulty swallowing
[ ] I lack support from my community
[] simply forgot
[ ] I don't have enough privacy to take pills
[ ] no time
[ ] I don't have enough privacy at the clinic
[ ] other (fill in)

[ ] I don't want to take medication 
b. Which of the following help would make you take your pills properly? You can tick more than one box.
[ ] information on when and how to take pills
[ ] drug more easily available
[ ] better support from doctors
[ ] less waiting time in pharmacy/hospital
[] better support from nurses
[ ] new and better drugs
[ ] better hospital facilities
[ ] automatic reminders via messages/apps
[ ] better community support
[] less stigma
[ ] support from traditional healer
[ ] HIV education in community
[ ] support from family/friends
[ ] other (fill in)

c. In some regions 'expert patients', who have received training from health professionals, are supporting and educating their fellow patients. They lead and organize peer support groups, which support patients through their lives. Do you think this is a good idea?
[] Yes;
[] No;
[] Maybe

Why:

d. What help from a fellow (or expert) patient do you feel is appropriate to support you?
[ ] driving together to hospital
[ ] provide drug stock-out information
[ ] help with what to say during doctor visit
[ ] provide information about medication use
[ ] provide information about my illness
[ ] give me emotional support
[ ] motivate me to take medication as prescribed
[ ] help me to make friends
[ ] help me to tell other people about my illness
[ ] tackling stigma

[ ] group member picking up medication for whole group

[ ] other (fill in)

e. To become an 'expert patient' a person with HIV will receive training by healthcare professionals in a short training program. Then they will voluntarily use their knowledge to support and educate fellow patients. Tasks could include being group leader, gathering information, distributing medication to other patients, becoming an educator etc.) Would you be interested in becoming such an expert patient?
[] Yes;
[ ] No;
[] Maybe

f. Would you like to attend regular peer support sessions that are led by an expert patient?
[ ] Yes;
[ ] No;
[] Maybe

g. How often would you be willing to attend peer support sessions?
[ ] once a week;
[ ] once every two weeks;
[ ] once every month

h. What would be your main concern regarding these peer support sessions? (fill in here:)

\section{DRUG DELIVERY}

a. How much time does it take in total to get your medication? (Including the time from leaving home until you return back home).
[ ] less than 1 hour;
[ ] 2-4 hours;
[ ] 4-6 hours;
[ ] >6 hours

b. How do you feel about how long it takes to pick up your medication? (draw a cross on the scale)
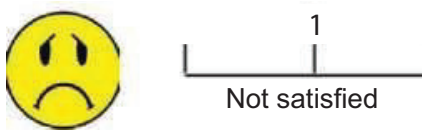

2

$\stackrel{3}{1}$

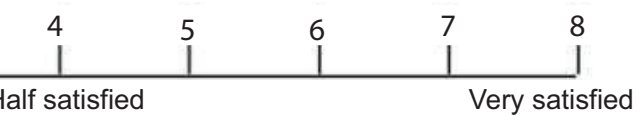

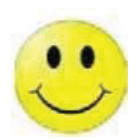


c. Would you consider joining a local peer support group, where you would receive your medication, so that you don't have to pick up your medicines at the hospital so often?
[] Yes;
[] No;
[] Maybe

d. How would you feel if you saw a doctor less often? I feel a doctor's visit is necessary:
[ ] once a month
[] once every 6 months
[] once every 2 months
[] when feeling ill
[ ] once every 3 months
[] when having concerns/issues about HIV

e. Would you feel more or less likely to take your drugs if you didn't visit the hospital as often?
[ ] More;
[] Less;
[ ] No difference;
[] Unsure 


\section{Supplement 2: Kiswahili Questionnaire}

\section{Dodosa juu ya 'wagonjwa wanaosaidiana' (Kiswahili)}

Msaili:

Tarehe:

Namba ya mgonjwa:

Numba ya utafiti:

\section{Maelekezo}

Umekuwa sehemu ya tafiti ya awali ya kuchunguza iwapo "msaada rafiki" unapokelewa na kujua kama una maoni gani. Majibu yako yatasaidia wahudumu wa afya kuboresha huduma kwa watu wanaotumia dawa za kupunguza nguvu ya virusi vya ukimwi (VVU). Tafadhali jibu kwa umakini kadili uwezavyo.- tueleze nini wewe binafsi unataka kusikia na sio unachofikiri sisi tunapenda kusikia. Maelezo yako hayataandikwa jina na hivyo kuweza kuhusishwa na wewe moja kwa moja

\section{MASWALI YA MSINGI}

a. Umri wako ni upi?
[ ] chini ya 20;
[ ] 20-40;
[ ] 40-65;
[ ] $>65$

b. Jinsia yako ni ipi?
[ ] Mme;
[] Mke;
[ ] Nyingine

c. Kiwango cha kipato chako ni kipi?
[ ] Chini ya 100,000 Tsh
[ ] 500,000 Tsh - 1,500,000 Tsh
[ ] 100,000 Tsh to 500,000 Tsh
[] Zaidi 1,500,000 Tsh

d. Je ni lini ulipima kwa mara ya kwanza kama na kugunduliwa kuwa na virusi vya ukimwi $(\mathrm{VVU})$ ? (mwaka)

\section{KIKUNDI CHA WAGONJWA WANAOSAIDIANA}

a. Wagonjwa wengi wanapata ugumu kumeza dawa zao, kwa sababu mbalimbali. Kama ulikosa kumeza dawa zako, sababu kubwa ilikuwa ipi? Unaweza kujaza kisanduku zaidi ya kimoja.
[ ] Sijawahi kukosa dawa zangu
[ ] Dawa zinanifanya niumwe
[ ] Dawa kuisha kwenye famasi/kliniki
[ ] Sijui dawa zinavyofanya kazi
[ ] Kupoteza muda wakati ninapoendea kliniki
[ ] Sijui muda na jinsi ya kunywa dawa kuchukua dawa
[ ] Nakosa msaada familia na ndugu
[ ] Nakosa msaada wa wahudumu wa hospitali
[ ] Dawa zina radha mbya
[ ] Nakosa msaada wa jamii
[ ] Ugumu wa kumeza vidonge
[ ] Sipati faragha ya kunywa dawa zangu
[ ] Huwa najisahau tu
[ ] Sipati faragha nikiwa kliniki
[] Sina muda
[ ] Sipendi kunywa dawa
[ ] Nyingine (jaza)

b. Yapi kati ya haya yafuatayo yangeweza kukusaidia kuhakikisha unameza vidonge vyako bila kukosa? Unaweza ukachagua zaidi ya kisanduku kimoja.
[ ] Kupatiwa maelezo ya wakati na jinsi ya kumeza vidonge
[ ] Dawa ziwe zinapatikana kirahisi
[ ] msaada zaidi toka kwa daktari
[ ] Imuda mfupi wa kusubiri kliniki na famasi 

[ ] msaada zaidi toka kwa nesi
[ ] huduma bora na vifaa vya hospitali
[ ] msaada kutoka kwa jamii
[ ] msaada wa tabibu wa asili
[ ] msaada wa familia na marafiki

[ ] dawa mpya na bora zaidi

[ ] mifumo ya kukumbusha kupitia sms/app za simu

[ ] kutokuwepo unyanyapaa

[ ] Elimu ya VVU kwa jamii

[ ] nyingine (jaza)

c. Sehemu nyingine duniani 'wagonjwa wataalam' waliosomeshwa na wanatauluma wa afya, wanatoa msaada kwa wenzao wagonjwa. Hawa huongoza "makundi ya kusaidiana", hivyo kusaidiana katika maisha yao. Je unaona kuwa hili ni wazo zuri?
[ ] Ndiyo;
[ ] Hapana;
[] Pengine

Kwanini (sababu):

d. Msaada wa aina gani ungependa (watalaam) hawa wagonjwa wakupatie?
[ ] kupanda gari na kwenda pamoja hospitali pamoja
[ ] kusaidiana jinsi ya kuongea na daktari
[ ] kuwapasha habari za kuumwa kwangu
[ ] Kunitia nguvu kunywa dawa kama nilivyoelekezwa
[ ] kunisaidia kuweza kuwambiaa watu wengine kuhusu ugonjwa wangu
[ ] provide drug stock-out information
[ ] kubadilishana maelezo ya jinsi ya kutumia dawa
[ ] kupewa msaada wa kimawazo
[ ] kunisadia kupata marafiki
[ ] kupambana na unyanyapaa
[ ] Wana kundi kwenda kufwata dawa kwa pamoja
[ ] nyingine (jaza)

e. Kuwa 'mgonjwa mtaalam' mtu mwenye VVU atapatiwa mafunzo na wataalam wa afya katika mafunzi mafupi. Baadae kwa haiari yao watatumia elimu yao kuwasaidia na kuwaelimisha wagonjwa wenzao. Baadhi ya kazi ni kama kuwa kiongozi wa kundi, kukusanya taarifa, kugawa dawa kwa wagonjwa wengine, kuwa msomeshaji n.k. Je ungependa kuwa 'mgonjwa mtaalam'?
[ ] Ndiyo;
[ ] Hapana;
[] Pengine

f. Je ungependa kuudhuria mikutano ya kikundi cha wagonjwa kusaidiana mara kwa mara, inayoongozwa na 'mgonjwa mtaalam'?
[ ] Ndiyo;
[ ] Hapana;
[] Pengine

g. Mara ngapi ungekuwa radhi kuhudhuria mikutano ya vikundi vya wagonjwa kusaidiana ?
[ ] mara moja kwa wiki;
[ ] mara moja kila wiki mbili;
[ ] mara moja kila mwezi

h. Je hoja yako kubwa ingekuwa nini kuhusiana na kundi la kusaidiana?

\section{UTOAJI WA DAWA}

a. Je kwa ujumla unachukua mda gani kupata dawa zako? (jumuisha muda wa kutoka nyumbani mpaka utakaporudi tena nyumbani).
[ ] chini ya saa moja;
[ ] masaa 2-4;
[ ] masaa 4-6;
[ ] masaa $>6$

b. Unatathmini vipi muda unaotumia kupata dawa zako ? ( Zungushia kwenye skeli)

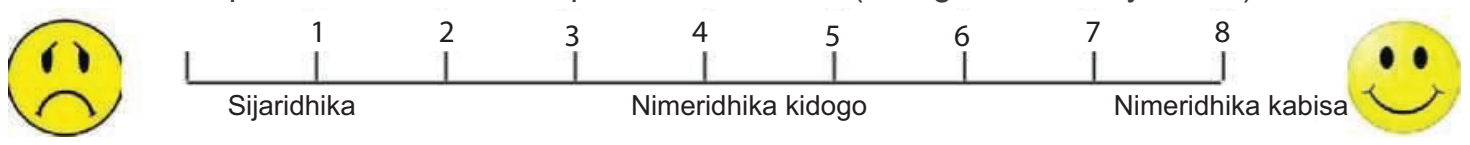


c. Je ugekubali kujiunga kliniki kwako na kundi la la wagonjwa la kusaidiana? Mahali ambapo kundi hili hukutana ili usiende mara kwa mara katika hospitali?
[ ] Ndiyo;
[ ] Hapana;
[ ] Pengine

d. Je unaonaje kama ungekuwa unaonana na daktari wako mara chache zaidi? Unadhani kumuona daktari ingekuwa muhimu:
[ ] mara moja kwa mwezi
[ ] mara moja kila miezi 6
[ ] mara moja kila miezi
[ ] wakati nikiwa mgonjwa tu
[ ] mara moja kila miezi 3
[ ] wakati nikiwa na hoja/swali/tatizo kuhusu
VVU

e. Je ungejisikia rahisi zaidi kutumia dawa zako iwapo hakuna haja ya kufika hospitali mara kwa mara?
[ ] Zaidi sana;
[ ] Pungufu;
[ ] Hakuna tofauti;
[ ] Sina hakika 


\section{Supplement 3: Raw Data}

\begin{tabular}{|c|c|c|}
\hline \multicolumn{3}{|c|}{ RAW DATA } \\
\hline \multirow{5}{*}{ What is your age? } & Under 20 & 3 \\
\hline & $20-40$ & 11 \\
\hline & $40-65$ & 10 \\
\hline & $>64$ & 0 \\
\hline & NA & 3 \\
\hline \multirow{3}{*}{ What is your sex? } & Male & 13 \\
\hline & Female & 11 \\
\hline & NA & 3 \\
\hline \multirow{5}{*}{ Which is your income range? } & Less than 100000 Tsh & 22 \\
\hline & 1000000 Tsh to 500000 Tsh & 2 \\
\hline & 500000 Tsh - 1500000 Tsh & 1 \\
\hline & More than $1500000 \mathrm{Tsh}$ & 0 \\
\hline & NA & 2 \\
\hline When did you first have a positive HIV test result? & & Open question \\
\hline \multirow{17}{*}{$\begin{array}{l}\text { Most patients experience some difficulties taking } \\
\text { their drugs, the reason why can vary. If you missed } \\
\text { taking your pills, what is the main reason? }\end{array}$} & A. I never missed taking my pills & 13 \\
\hline & B. Pharmacy stock-out & 1 \\
\hline & $\begin{array}{l}\text { C. Too much time lost to pick up } \\
\text { medication }\end{array}$ & 5 \\
\hline & \begin{tabular}{|l|} 
D. I lack support from family/ \\
friends
\end{tabular} & 7 \\
\hline & $\begin{array}{l}\text { E. I lack support from hospital } \\
\text { staff }\end{array}$ & 1 \\
\hline & $\begin{array}{l}\text { F. I lack support from my commu- } \\
\text { nity }\end{array}$ & 3 \\
\hline & $\begin{array}{l}\text { G. I don't have enough privacy to } \\
\text { take pills }\end{array}$ & 1 \\
\hline & $\begin{array}{l}\text { H. I don't have enough privacy at } \\
\text { the clinic }\end{array}$ & 2 \\
\hline & I. The drugs make me feel sick & 1 \\
\hline & $\begin{array}{l}\text { J. I am not sure the medication is } \\
\text { working }\end{array}$ & 3 \\
\hline & $\begin{array}{l}\text { K. Not sure how and when to take } \\
\text { the pills }\end{array}$ & 2 \\
\hline & L. I don't want to take medication & 4 \\
\hline & M. The medication tastes bad & 4 \\
\hline & N. Difficulty swallowing & 2 \\
\hline & O. I simply forgot & 8 \\
\hline & P. No time & 2 \\
\hline & Q. Other & 7 \\
\hline
\end{tabular}




\begin{tabular}{|c|c|c|}
\hline \multirow{13}{*}{$\begin{array}{l}\text { Which of the following help would make you take } \\
\text { your pills properly? You can tick more than one box. }\end{array}$} & $\begin{array}{l}\text { A. Information on when and how } \\
\text { to take pills }\end{array}$ & 15 \\
\hline & $\begin{array}{l}\text { B. Less waiting time in pharmacy/ } \\
\text { hospital }\end{array}$ & 5 \\
\hline & $\begin{array}{l}\text { C. Automatic reminders via } \\
\text { messages/apps }\end{array}$ & 12 \\
\hline & D. Better hospital facilities & 8 \\
\hline & E. HIV education in community & 17 \\
\hline & F. Less stigma & 18 \\
\hline & G. Drug more easily available & 9 \\
\hline & H. New and better drugs & 6 \\
\hline & I. Better support from doctors & 11 \\
\hline & J. Support from family/friends & 7 \\
\hline & K. Better support from nurses & 9 \\
\hline & L. Better community support & 2 \\
\hline & M. Support from traditional healer & 4 \\
\hline \multirow{4}{*}{$\begin{array}{l}\text { In some regions 'expert patients', who have } \\
\text { received training from health professionals, are } \\
\text { supporting and educating their fellow patients. } \\
\text { They lead and organize peer support groups, which } \\
\text { support patients through their lives. Do you think } \\
\text { this is a good idea? }\end{array}$} & Yes & 25 \\
\hline & No & 0 \\
\hline & Maybe & 0 \\
\hline & NA & 2 \\
\hline \multirow{12}{*}{$\begin{array}{l}\text { What help from a fellow (or expert) patient do you } \\
\text { feel is appropriate to support you? }\end{array}$} & A. Driving together to hospital & 4 \\
\hline & $\begin{array}{l}\text { B. Group member picking up } \\
\text { medication for whole group }\end{array}$ & 3 \\
\hline & $\begin{array}{l}\text { C. Provide information about } \\
\text { medication use }\end{array}$ & 9 \\
\hline & $\begin{array}{l}\text { D. Provide drug stock-out } \\
\text { information }\end{array}$ & 8 \\
\hline & $\begin{array}{l}\text { E. Motivate me to take } \\
\text { medication as prescribed }\end{array}$ & 21 \\
\hline & $\begin{array}{l}\text { F. Help me to tell other people } \\
\text { about my illness }\end{array}$ & 4 \\
\hline & $\begin{array}{l}\text { G. Provide information about my } \\
\text { illness }\end{array}$ & 6 \\
\hline & H. Give me emotional support & 17 \\
\hline & I. Help me to make friends & 8 \\
\hline & J. Tackling stigma & 18 \\
\hline & $\begin{array}{l}\text { K. Help with what to say during } \\
\text { doctor visit }\end{array}$ & 5 \\
\hline & L. Other & 2 \\
\hline
\end{tabular}


To become an 'expert patient' a person with HIV will receive training by healthcare professionals in a short training program. Then they will voluntarily use their knowledge to support and educate fellow patients. Tasks could include being group leader, gathering information, distributing medication to other patients, becoming an educator etc.) Would you be interested in becoming such an expert patient?

Would you like to attend regular peer support sessions that are led by an expert patient?

How often would you be willing to attend peer support sessions?

What would be your main concern regarding these peer support sessions? (fill in here:)

How much time does it take in total to get your medication? (Including the time from leaving home until you return back home).

How do you feel about how long it takes to pick up your medication? (draw a cross on the scale)

Would you consider joining a local peer support group, where you would receive your medication, so that you don't have to pick up your medicines at the hospital so often?

How would you feel if you saw a doctor less often? I feel a doctor's visit is necessary:

Would you feel more or less likely to take your drugs if you didn't visit the hospital as often?

\begin{tabular}{|c|c|}
\hline Yes & 18 \\
\hline No & 3 \\
\hline Maybe & 2 \\
\hline NA & 4 \\
\hline Yes & 22 \\
\hline No & 3 \\
\hline Maybe & 0 \\
\hline NA & 2 \\
\hline Once a week & 7 \\
\hline Once every two weeks & 1 \\
\hline Once a month & 17 \\
\hline \multirow[t]{2}{*}{ NA } & 2 \\
\hline & Open question \\
\hline Less than 1 hour & 2 \\
\hline 2-4 hours & 7 \\
\hline 4-6 hours & 11 \\
\hline$>6$ hours & 5 \\
\hline NA & 2 \\
\hline Average & 5.44 \\
\hline SD & 1,733794 \\
\hline Yes & 14 \\
\hline No & 10 \\
\hline Maybe & 2 \\
\hline NA & 1 \\
\hline \multicolumn{2}{|c|}{ Question deleted due to translation error. } \\
\hline More & 7 \\
\hline Less & 5 \\
\hline No difference & 7 \\
\hline Unsure & 3 \\
\hline NA & 5 \\
\hline
\end{tabular}

